\title{
ROZWIJANIE KOMPETENCJI MIĘDZYKULTUROWEJ ZA POMOCAૃ KSIĄŻEK O POLSCE NAPISANYCH PRZEZ CUDZOZIEMCÓW
}

\begin{abstract}
Słowa kluczowe: kompetencja międzykulturowa, komunikacja międzykulturowa, dialog międzykulturowy, język polski jako obcy, książki cudzoziemców o Polsce

Streszczenie. W artykule szczegółowo zanalizowane zostały - z perspektywy podejścia międzykulturowego do nauczania języków obcych - dwie książki autorstwa cudzoziemców poświęcone kulturze polskiej: Berlin-Warszawa-Express. Pociag do Polski (2013) Steffena Möllera i Jestem Kazu. Japończyk w Polsce (2017) Kazutaki Sasakiego. Autorka uzasadnia, dlaczego tego rodzaju teksty stanowią znakomity materiał do rozwijania kompetencji międzykulturowej na zajęciach języka polskiego jako obcego, której definicję i metody kształtowania przypomina w artykule. Podkreśla, że książki obcokrajowców stwarzają na lekcji możliwość poznawania nie tylko kultury polskiej, ale także kultur reprezentowanych przez autorów tych publikacji, a ponadto pozwalają uczącym się na naturalne wypowiedzi na temat swoich rodzimych kultur w kontekście porównań z kulturą polską. Artykułowi towarzyszą autorskie propozycje ćwiczeń ukierunkowanych na dialog międzykulturowy w procesie nauczania polszczyzny, które oparte zostały na wybranych fragmentach omawianych książek.
\end{abstract}

\section{KOMPETENCJA MIĘDZYKULTUROWA}

Lekcje języków obcych zdają się szczególnie predestynowane do tego, żeby uwrażliwiać na różnice kulturowe oraz uczyć efektywnej i bezkonfliktowej komunikacji z przedstawicielami odrębnych kultur. Wszak poznawanie języka i kultury,

*j.zych@uw.edu.pl, Uniwersytet Warszawski, Wydział Polonistyki, Centrum Języka Polskiego i Kultury Polskiej dla Cudzoziemców Polonicum, ul. Krakowskie Przedmieście 26/28, 00-927 Warszawa. 
której jest on nośnikiem, stanowi nierozłączny proces. W dydaktyce języków obcych odpowiedzią na wyzwania współczesności jest podejście międzykulturowe. Jego główny cel stanowi „uwarunkowane kulturowo pogłębianie zdolności komunikowania się" (Gębal 2019, s. 199). Magdalena Białek dokonała przeglądu licznych definicji dwóch kluczowych pojęć odnoszących się do kształcenia międzykulturowego w edukacji językowej, a mianowicie kompetencji międzykulturowej i komunikacji międzykulturowej. Doszła do wniosku, że te terminy są ze sobą ściśle skorelowane i wzajemnie się warunkują. Kompetencja międzykulturowa jest bowiem niezbędna do aktywnego uczestniczenia w komunikacji międzykulturowej (Białek 2009, s. 38).

Wielu badaczy przedstawiło własną propozycję definicji kompetencji międzykulturowej. Nie sposób przywołać ich wszystkich, trzeba jednak przypomnieć koncepcję Michaela Byrama, wykorzystywaną najczęściej na gruncie glottodydaktyki. Beata Karpińska-Musiał zauważa, że to właśnie na tę definicję powołuje się większość autorów prowadzących badania nad dialogiem międzykulturowym w kontekście nauczania języków obcych, zarówno w Polsce, jak i za granicą (Karpińska-Musiał 2015, s. 104). Byram ukuł pojęcie międzykulturowej kompetencji komunikacyjnej. W ujęciu tego badacza kompetencja międzykulturowa, na którą składają się postawy, wiedza, umiejętności oraz krytyczna świadomość kulturowa, współwystępuje z kompetencją językową, socjolingwistyczną i dyskursywną - tworzą one łącznie międzykulturową kompetencję komunikacyjną (Byram 1997). Kompetencja międzykulturowa stanowi więc integralną część kompetencji komunikacyjnej. Poszczególne komponenty tej złożonej kompetencji zostały szczegółowo opisane przez autora, a następnie zreferowane i uzupełnione przez kontynuatorów jego myśli. Wiedzy o kulturze rodzimej i o poznawanej kulturze innego społeczeństwa towarzyszyć powinna postawa otwartości i ciekawości wobec innych kultur, jak również gotowość do powstrzymywania się od ich wartościowania. Natomiast przez umiejętności Byram rozumie zdolność do interpretacji, czyli wyjaśniania przejawów kultury obcej i porównywania jej z własną, a także umiejętność zdobywania wiedzy o kulturze i zastosowania jej w konkretnej sytuacji komunikacyjnej. Wreszcie krytyczna świadomość kulturowa jest tożsama ze zdawaniem sobie sprawy z własnych przekonań i z wpływu różnic kulturowych na porozumienie (Bandura 2007, s. 57-62). Podsumowując ustalenia Byrama, Ewa Bandura definiuje kompetencję międzykulturową jako „znajomość podobieństw i różnic między stylami życia i poglądami charakterystycznymi dla różnych kultur oraz umiejętność zastosowania tej znajomości w praktycznej komunikacji” (Bandura 2007, s. 57).

W podejściu międzykulturowym odchodzi się od monokulturowego modelu realizacji zajęć językowych na rzecz kulturowego dwugłosu, a nawet wielogłosu. W świetle postulatu rozwijania kompetencji międzykulturowej stało się bowiem jasne, że treści kulturowe na lektoracie nie mogą się ograniczać do prezentacji 
kultury języka docelowego. Na zajęciach należy stworzyć przestrzeń do tego, żeby słuchacze mogli mówić w języku obcym również o swojej rodzimej kulturze i porównywać ją z tą, o której się uczą, a także odkrywać zwyczaje oraz tradycje koleżanek i kolegów z innych krajów, o ile nauka odbywa się w grupie wielonarodowościowej. Przemysław Gębal podkreśla, że „pojawienie się podejścia międzykulturowego w zasadniczy sposób zmieniło stosunek dydaktyki kultury do uczącego się" (Gębal 2019, s. 199), ponieważ kultura, z którą utożsamia się podmiot nauczania, została zaktywizowana dydaktycznie i stała się ważnym punktem odniesienia na lekcji. Natomiast faktograficzne i prezentacyjne ujęcie treści kulturowych ustąpiło miejsca ćwiczeniom ukierunkowanym na obserwację, refleksję, porównywanie, interpretowanie i stawianie hipotez na temat różnic czy nieporozumień kulturowych.

\section{JAK ROZWIJAĆ KOMPETENCJĘ MIĘDZYKULTUROWĄ?}

Istnieje wiele technik mających na celu rozwijanie kompetencji międzykulturowej na lekcjach języka obcego. Większość z nich ilustruje podejście kognitywne. Do najczęściej stosowanych materiałów służących do kształtowania tej kompetencji zalicza się teksty, filmy, wykłady i dyskusje na temat wybranych aspektów danej kultury lub różnic kulturowych, wskazywanie związków między kulturą a językiem, np. za pomocą idiomów i przysłów, czy różne formy dygresji kulturowych (Bandura 2007, s. 47-50; Wilczyńska i in. 2019, s. 623-639). Większość uczących się bardziej angażują zadania realizujące założenia podejścia działaniowego, np. minidramy polegające na odgrywaniu scenek typowych dla danej kultury albo projekty grupowe. Popularne są również gry, tj. Albatros czy Bafa Bafa, które wymagają od uczestników obserwacji, interpretacji i negocjacji (Spychała-Wawrzyniak 2016, s. 84-85). Wykorzystuje się także ćwiczenia znane $\mathrm{z}$ treningów międzykulturowych, tj. asymilatory kulturowe i incydenty krytyczne. Integralną częścią obu tych typów zadań jest opis nieporozumienia komunikacyjnego na tle różnic kulturowych. W przypadku asymilatora kulturowego zadaniem uczących się jest wybór właściwej interpretacji zdarzenia spośród podanych opcji, zaś po zapoznaniu się z incydentem krytycznym uczestnicy treningu muszą się zastanowić, jak można byłoby uniknąć tego konfliktu. Mamy do dyspozycji wiele podręczników z propozycjami podobnych ćwiczeń. Sięgnięcie po takie rozwiązania metodyczne, wykorzystywane m.in. w zarządzaniu, może pomóc nauczycielom w przygotowaniu efektywnych zajęć rozwijających kompetencję międzykulturową (Kossakowska-Pisarek 2016, s. 61). Wydaje się jednak, że takie techniki są nadal rzadko stosowane przez lektorów języków obcych. Warto przypomnieć, że cenną pomocą dla nauczycieli poszukujących inspiracji, jak 
integrować edukację międzykulturową z innymi celami zajęć językowych, jest publikacja Autobiografia spotkań międzykulturowych, opracowana przez Byrama i jego współpracowników.

Przydatne w kontekście poszukiwań optymalnej metody włączania do lekcji treści międzykulturowych są ustalenia Marty Torenc, która zaproponowała czytelną klasyfikację aktywności służących kształceniu kompetentnych uczestników komunikacji międzykulturowej. Wyróżniła cztery typy zadań: stwarzające warunki do obserwacji, wymagające interpretacji, będące bodźcem do działania oraz stawiające uczących się przed koniecznością eksplikacji i oceny (Torenc 2007, s. 132-137). Wskazała także zasady, którymi należy się kierować przy konstruowaniu takich ćwiczeń. Wśród wielu wymienionych szczególnie ważny wydaje się imperatyw aktywności, czyli angażowania uczniów w proces dydaktyczny. Jako równie istotna jawi się zasada autopoznania, tj. odwoływania się do doświadczeń uczących się i umożliwiania im pogłębionej refleksji o samym sobie dzięki kontaktowi z innością kulturową. Warto mieć też zawsze na uwadze zasadę różnorodności, która przypomina, że każdy uczeń inaczej postrzega dany materiał na zajęciach, a jego odbiór jest uzależniony m.in. od wiedzy, przekonań i kontaktów międzykulturowych. Wreszcie, kluczowa jest zasada autentyczności, która powinna umożliwić „konfrontację własnego działania językowego oraz teorii subiektywnych leżących u jego podstaw z językowym i pozajęzykowym działaniem innych (Torenc 2007, s. 143).

\section{TEKSTY CUDZOZIEMCÓW O POLSCE JAKO MATERIAL NA ZAJECIA}

W świetle przytoczonych reguł można twierdzić, że znakomitą propozycję na zajęcia języka polskiego jako obcego, ukierunkowane na rozwijanie kompetencji międzykulturowej, stanowią wypowiedzi cudzoziemców o Polsce i Polakach. Są to bowiem teksty autentyczne oparte na konkretnych przeżyciach realnych osób, które zetknęły się z innością kulturową. Autorzy dzielą się swoimi doświadczeniami z dłuższego pobytu w obcym kraju i z kontaktów z przedstawicielami odmiennej kultury. Oczywiście w kontekście nauczania polszczyzny najistotniejszy jest fakt, że w przypadku takich publikacji to Polacy uosabiają inność, a dialog międzykulturowy przedstawiony jest nie z perspektywy polskiej, jak to się zwykle odbywa na lektoracie, ale z punktu widzenia obcokrajowców, którzy odkrywają Polskę, jej mieszkańców i ich zwyczaje. Wybór takiego tekstu wydaje się posunięciem $\mathrm{w}$ pełni zgodnym z założeniami podejścia międzykulturowego. Można nawet zaryzykować twierdzenie, że jest modelową realizacją postulatu rozwijania kompetencji międzykulturowej. $\mathrm{Z}$ jednej strony jak najbardziej umożliwia pre- 
zentację różnych aspektów kultury polskiej, z drugiej zaś wymusza zdystansowanie się od niej i spojrzenie na nią w sposób nowy i odkrywczy, bo oczami przedstawicieli innych kultur. Dzięki temu uczący się będą mogli poznawać kulturę polską nie tak, jak chciałby im ją zaprezentować nauczyciel-Polak, który się z nią identyfikuje, ale tak, jak ją widzą obcokrajowcy. Cudzoziemcy nie tylko mają do niej większy dystans i dostrzegają znaczące szczegóły, które niekiedy umykają Polakom, ale też opisują ją przez pryzmat rodzimej kultury, co automatycznie wprowadza na zajęcia treści kulturowe dotyczące innych krajów. W tekstach przybyszy z zagranicy piszących o Polsce nieuniknione są bowiem porównania, odniesienia i odwołania do własnej kultury, tak jak w przypadku każdego spotkania międzykulturowego.

Taki materiał może być pozytywnym zaskoczeniem dla uczestników zajęć. Po pierwsze, jest to niestandardowy i nieoczekiwany sposób inicjacji rozmowy o kulturze polskiej. Typowy scenariusz takiej lekcji obejmuje opis wybranego wątku polskiej kultury, po którego omówieniu następuje próba skierowania dyskusji na tory podobieństw i różnic w innych kulturach. W przypadku tekstu o Polsce autorstwa cudzoziemca perspektywa międzykulturowa jest od początku naturalnie obecna. Po drugie, taka propozycja metodyczna pozwala skutecznie uniknąć niebezpieczeństwa polonocentryzmu, co więcej - dopuszcza ewentualną krytykę kultury polskiej w wypowiedziach obcokrajowców. Warto odwołać się w tym kontekście do socjologii i filozofii. Przypomnijmy słowa Georga Simmla o obiektywizmie i wolności właściwych opiniom przybyszy o obcych im społecznościach. Niemiecki socjolog stwierdził, że cudzoziemiec „obserwuje sytuację bardziej bezstronnie, ocenia ją, stosując bardziej ogólne i obiektywne kryteria, w swym działaniu pozostaje nieskrępowany przyzwyczajeniem, nabożnym szacunkiem ani tradycją" (Simmel 1975, s. 507). Zygmunt Bauman także podkreślał niezależność i odkrywczość sądów Obcego, który „,nieświadom jest miejscowych zwyczajów - i z tego powodu staje się tym człowiekiem, który kwestionuje wszystko nieomal, co z punktu widzenia grupy, do której wkracza, nie ulega kwestii” (Bauman 2000, s. 21). Po trzecie, zabieg ten wyraźnie sygnalizuje chęć uwzględnienia na zajęciach spostrzeżeń i opinii cudzoziemców, jest zaproszeniem do dzielenia się swoimi doświadczeniami w odkrywaniu kultury polskiej. Jej charakterystyki w wykonaniu obcokrajowców mają duży potencjał, jeżeli chodzi o aktywizację uczących się. Wszak każdy cudzoziemiec, który miał kontakt z Polakami i/lub był w Polsce, ma o tym coś do powiedzenia, a autentyczne teksty na ten temat napisane przez osoby, z którymi może się utożsamiać, mają szansę go ośmielić i zachęcić do własnych wypowiedzi. Dają też uczącym się możliwość skonfrontowania swoich obserwacji i przemyśleń o Polsce i jej mieszkańcach z tym, co zauważyli inni obcokrajowcy. Oczywiście takie materiały skłaniają także do świadomej refleksji o rodzimej kulturze i do zastanowienia się nad pewnymi ogólnymi mechanizmami rządzącymi kontaktami 
międzykulturowymi. Dialog międzykulturowy nieuchronnie zmusza do przemyśleń o „tożsamości własnej i tej nowej, nabywanej w komunikacji międzykulturowej" (Żydek-Bednarczuk 2015 , s. 21).

Publikowanych jest coraz więcej wypowiedzi cudzoziemców na temat Polaków i kultury polskiej. W niniejszym artykule analizie z perspektywy podejścia międzykulturowego poddane zostaną dwie wydane przed kilku laty książki autorstwa cudzoziemców, będących przedstawicielami różnych krajów i pokoleń. Obie publikacje poświęcone są kulturze polskiej widzianej oczyma przybysza z zagranicy oraz dialogowi międzykulturowemu, a są to: Berlin-Warszawa-Express. Pociag do Polski (2013) Steffena Möllera i Jestem Kazu. Japończyk w Polsce (2017) Kazutaki Sasakiego. Na podstawie fragmentów tych książek zostaną także zaproponowane ćwiczenia na zajęcia języka polskiego jako obcego, mające na celu rozwijanie kompetencji międzykulturowej. Niektóre spośród nich nawiązują bezpośrednio do opisanych technik wykorzystywanych w treningach międzykulturowych.

\section{NIEMIECKI PRZEWODNIK PO POLAKACH}

Po posiadaczu tak bogatego portfolio spotkań międzykulturowych jak Steffen Möller - poliglota i człowiek, który ma w swojej biografii liczne pobyty za granicą - można się spodziewać szczególnej wrażliwości i refleksyjności odnośnie do różnic kulturowych. Świadectwem niemal profesjonalnej znajomości zasad komunikacji międzykulturowej jest jego publikacja Berlin-Warszawa-Express. Pociag do Polski (2013). Pomysł na formułę książki autor zaczerpnął ze swojego doświadczenia podróżnego korzystającego często z linii kolejowej łączącej niemiecką i polską stolicę. Podczas kilkugodzinnej podróży pociągiem z Berlina do Warszawy Möller opowiada o Polsce i Polakach, a pretekstem do tych opowieści jest wszystko to, co widzi i słyszy w czasie jazdy: mijane po drodze stacje i krajobrazy, wygląd, rozmowy i zachowanie współpasażerów czy menu w wagonie restauracyjnym. Jest to więc coś na kształt fabularyzowanego przewodnika. Opis wydarzeń rozgrywających się w ciągu kilku godzin na trasie Berlin-Warszawa wzbogacony jest licznymi dygresjami o kulturze polskiej i niemieckiej oraz komentarzami i anegdotami na temat różnic i nieporozumień kulturowych między Polakami a Niemcami. Opis oferty wagonu restauracyjnego Wars stanowi pretekst do przytoczenia legendy o legendarnych założycielach Warszawy, a widok posągu Chrystusa Króla na stacji w Świebodzinie skłania autora do podjęcia wątku religijności Polaków. Koncepcja książki okazuje się nośna, bo pozwala poruszyć w naturalnym kontekście wiele aspektów kultury polskiej, m. in. geografię, historię, gospodarkę, politykę, święta i zwyczaje, popkulturę czy mentalność Polaków. 
Kolejne odcinki podróży wyznaczają tytuły rozdziałów książki oraz dyktują ich tematykę. Rozdziały podzielone zostały zaś na wiele sekcji tematycznych. Warto przytoczyć kilka tytułów, ponieważ odzwierciedlają one różnorodność zagadnień podjętych przez Möllera oraz jego ambicję stworzenia możliwie wyczerpującego kompendium wiedzy o różnicach kulturowych między Niemcami a Polakami: Apfelschorle kontra bawarka; Fakty o Polakach w Niemczech; Mieszkaniowy szat; Ostrzegaj, a nie pouczaj; Kultura kioskowa; Emocje w Niemczech; Włóż kapcie!; Boże Narodzenie po polsku; System opieki zdrowotnej. Jak widać, rozpiętość tematyczna jest rzeczywiście duża, jednak wyraźnie dominują te sfery kultury, które Waldemar Pfeiffer określił w swojej znanej klasyfikacji mianem krajoznawstwa i socjoznawstwa (Pfeiffer 2001, s. 157-159).

Möller często nawiązuje do mocno zakorzenionych w obu kulturach stereotypów narodowościowych, które wypaczają obraz Polaków i Niemców w oczach sąsiadów, a przede wszystkim utrudniają im wzajemne poznanie się i rzeczywisty dialog. Demaskuje nieprawdziwość lub nieaktualność wielu takich obiegowych wyobrażeń. Autor wykazuje m.in. nieadekwatność przekonania, że już na pierwszy rzut oka można rozpoznać, kto jest Polakiem, a kto Niemcem. Przyznaje się, że lubi zgadywać podczas podróży, który z pasażerów czekających na dworcu jest jego rodakiem, a który - obywatelem Polski. Przypomina, że jeszcze pod koniec $\mathrm{XX}$ wieku było to proste, bo obie nacje zdradzały typowe stroje, fryzury czy akcesoria, tj. sumiasty wąs i torby w kratkę w przypadku Polaków oraz szare ubrania i plecaki jako rekwizyty Niemców. Kwituje jednak te dywagacje stwierdzeniem, że w XXI wieku taka błyskawiczna i nieomylna identyfikacja nie jest już możliwa, bo ludzie po obu stronach granicy noszą się teraz w zasadzie identycznie.

Möller zauważa, że przynależność do danej kultury narodowej czy raczej wychowanie w tej kulturze zdradzają głównie mowa ciała, mimika i najprostsze gesty, których nawet sobie na co dzień nie uświadamiamy. Żeby udowodnić prawdziwość tej tezy, inscenizuje w swojej książce zabawną scenę w wagonie restauracyjnym Wars. Jej uczestnikami są niemiecki biznesmen, doktor Harald Schwechtersheimer, oraz młode polsko-niemieckie małżeństwo, Dorota i Tomek. Dorota jest wprawdzie z pochodzenia Polką, ale dorastała w Niemczech. Dlatego też posługuje się sztućcami inaczej niż jej mąż, który wychował się w Polsce. Ponoć odmienny sposób trzymania noża i widelca stanowi jedyny sporny temat w tym zgodnym związku. Pan Schwechtersheimer uświadamia sobie tę różnicę dotyczącą savoir-vivre dopiero wtedy, gdy sam sięga po widelec - „ze zdziwieniem zauważa, że w istocie trzyma go tak jak Dorota" (Möller 2013, s. 71).

Möller przywołuje wiele konkretnych sytuacji, które odpowiadają definicji nieporozumienia na tle kulturowym albo nawet incydentu krytycznego. Opowiada m.in. o dyrektorze wrocławskiego muzeum, który przez kilka godzin z zaangażowaniem oprowadzał po swojej placówce grupę z Niemiec i nie potrafił ukryć irytacji, gdy pod koniec wycieczki jeden z jej uczestników zwrócił mu uwagę, że „w sali 
barokowej oderwała się pozłacana listwa na ścianie" (Möller 2013, s. 64). Autor tłumaczy, że w zachowaniu zwiedzającego nie należy się doszukiwać złośliwej pedanterii, lecz przeciwnie, trzeba je uznać za przejaw wdzięczności za czas poświęcony mu przez przewodnika. Podaje także przykład niefortunnej komunikacji, jaka stała się udziałem pewnej polsko-niemieckiej pary. Podczas kolacji w restauracji Polka oświadczyła, że jest jej zimno, na co Niemiec odpowiedział, że nie odczuwa chłodu. Jego towarzyszka nie tylko się zdenerwowała, ale też zarzuciła mu brak dobrego wychowania. Möller wyjaśnia, że o ile Polacy nie mają wątpliwości, że wypowiedź kobiety wyraźnie sygnalizowała oczekiwanie jakiegoś działania ze strony partnera, np. zaoferowania własnej marynarki jako okrycia, o tyle dla Niemców taki implicytny przekaz nie ma wcale wydźwięku performatywnego (Möller 2013, s. 85). Ten incydent krytyczny ilustruje jedną z kluczowych charakterystyk kultury niemieckiej, jaką jest bezpośrednia i dosłowna komunikacja. Przypomnijmy, że specjaliści w zakresie komunikacji międzykulturowej sytuują Niemcy wśród tzw. kultur niskiego kontekstu, w których ludzie wyrażają swoje myśli wprost i oczekują równie jasnych komunikatów od innych (Meyer 2014, s. 39).

Autor z dumą podkreśla, że świadomie pełni rolę podwójnego ambasadora - kultury polskiej i niemieckiej. W przewodniku wyraźnie obecne są także wątki interkulturowe, a niektóre jego fragmenty Möller wprost nazywa elementami treningu międzykulturowego. O samym sobie pisze żartobliwie, że zaczynał jako gastarbeiter w Polsce, a obecnie występuje w roli konsultanta emigracyjnego w Niemczech - tytuł Gastarbeiter-Emigration Consultant nosi pierwszy rozdział jego książki. Natomiast pod koniec przewodnika znajdziemy sekcję tematyczną zatytułowaną po prostu Interkulturowy dialog. Pojęcie to zostało jednak przewrotnie użyte w dwóch znaczeniach - nie tylko na poziomie meta jako określenie komunikacji i mediacji między różnymi kulturami, ale także całkiem dosłownie jako prozaiczna rozmowa między przedstawicielami dwóch nacji. Möller zauważa, jak istotna jest umiejętność naturalnej konwersacji z reprezentantami innej kultury. Podkreśla, że wymaga to orientacji w tematach uważanych w danym kraju za bezpieczne, bo niekontrowersyjne, a przy tym zajmujące dla wielu osób. Zdradza, że w Niemczech częstym tematem niezobowiązujących rozmów towarzyskich jest piłka nożna. Za typowy polski small talk uważa natomiast pogawędki o zbieraniu grzybów. Żeby usprawnić polsko-niemieckie konwersacje, swoim czytelnikom z obu krajów proponuje coś w rodzaju żartobliwego pomocnika konwersacyjnego, w którym w dwóch kolumnach zestawia najważniejsze informacje i pojęcia związane z futbolem i z grzybobraniem (Möller 2013, s. 213-216).

Wreszcie pod koniec książki Möller udowadnia, że opanował sztukę trudną ponoć dla Niemców, a właściwą Polakom - zdolność implicytnego formułowania przekazu. Okazuje się, że epizodyczna postać milczącego współpasażera, o którym autor wspominał niekiedy w przewodniku, jest bardzo istotna dla interkulturowej misji jego publikacji. Wśród podróżnych w wagonie Wars był młody 
Azjata, którego wziął za Japończyka. Dopiero pod koniec podróży Möller dowiaduje się, że przybysz z Dalekiego Wschodu jest Chińczykiem. W rozmowie z nim Niemiec pozwala sobie na niefrasobliwe wygłoszenie opinii, że „Japończyków generalnie łatwo pomylić z Chińczykami” (Möller 2013, s. 225), co wywołuje gwałtowny sprzeciw jego rozmówcy. „Ależ skąd! Niemcy i Polacy - tak, są bardzo podobni! Ale Chińczycy i Japończycy są zupełnie różni” (Möller 2013, s. 225), oponuje Mingliang. Skoro Europejczyk jest w stanie pomylić przedstawicieli dwóch zupełnie odmiennych kultur azjatyckich, nie dziwi też fakt, że z perspektywy mieszkańca Azji Wschodniej różnice między Polakami a Niemcami nie są tak oczywiste, jak wydaje się ludziom na Starym Kontynencie. Tak właśnie autor uzmysławia czytelnikom względność rzekomo znaczących różnic między narodami z obu stron Odry i podkreśla to, co je łączy i powinno zbliżać jako dwie sąsiednie nacje europejskie.

\section{JAPOŃSKA INSTRUKCJA OBSŁUGI POLSKI}

Dziennik Kazutaki Sasakiego zatytułowany Jestem Kazu. Japończyk w Polsce ukazał się w $2017 \mathrm{r}$. Autor po raz pierwszy znalazł się nad Wisłą jako dziewiętnastolatek w $2011 \mathrm{r}$. podczas swojej kilkumiesięcznej podróży po świecie. Trafił do Polski, a konkretnie do Poznania, przez przypadek. Będąc istną tabula rasa w dziedzinie wiedzy o Polsce, Sasaki nie miał żadnych wyobrażeń czy uprzedzeń co do tego kraju. Dzięki temu odkrywał jego kulturę spontanicznie - chłonął polską rzeczywistość podczas spacerów po mieście i przypadkowych rozmów. Swoje wspomnienia z pobytu w Poznaniu opisał w pierwszej części książki pod wymownym tytułem Na głęboka wodę. Już w Poznaniu Kazu nauczył się pierwszych słów po polsku dzięki pogawędkom z ludźmi spotykanymi w hostelach i barach. Po powrocie do Japonii utrzymywał znajomości z Polakami przez Internet. Po czterech latach ponownie wybrał się do kraju Chopina. Tym razem spędził w nim kilka miesięcy. Zatrzymywał się zwykle w domach swoich polskich znajomych, co pozwoliło mu dobrze poznać życie codzienne i relacje międzyludzkie w Polsce. Ten dłuższy akt swojej polskiej przygody opisał w kolejnych częściach książki pt. Ten drugi raz i Sushi master. Trzeba zaznaczyć, że w przeciwieństwie do Möllera cechowała go nikła świadomość różnic kulturowych, a jego umiejętności w zakresie komunikacji międzykulturowej opierały się wyłącznie na intuicji, nie zawsze zresztą trafnej. Dlatego w publikacji Jestem Kazu. Japończyk w Polsce nie znajdziemy metarefleksji o dialogu międzykulturowym, natomiast przeczytamy wiele autentycznych przykładów nieporozumień kulturowych.

Takie nieskażone obiegowymi opiniami obserwacje polskich realiów mogą być zaskakujące dla Polaków. Charakteryzując przestrzeń miejską w Poznaniu, 
Japończyk napisał m.in. „Przy okazji, wiecie, co najczęściej widziałem na ulicy w Polsce? Ulotki? Puste butelki? Biedronki? Nie. „KEBAB” (Sasaki 2017, s. 58). Niektóre opisy polskich zwyczajów i tradycji, jakie znajdziemy w książce, mogą się wydać polskim czytelnikom zbyt uproszczone i powierzchowne. $Z$ obserwacji ludzi w kościele cudzoziemiec wyniósł przekonanie, że podczas ceremonii religijnej w Polsce należy „klęczeć i żegnać się” (Sasaki 2017, s. 62). Autor zapisywał po prostu to, co widział, ale często nie rozumiał szczegółów i niuansów sytuacji, których był świadkiem. Jego dziennik można traktować jako autentyczny dokument kontaktu z inną kulturą, swoistą autobiografię międzykulturowego spotkania z Polską.

Egzotyczna okazała się dla Kazu polska rzeczywistość w swoim najbardziej fizycznym i namacalnym wydaniu. Zobaczył tu po raz pierwszy wiele rzeczy, sprzętów i urządzeń, których przeznaczenia nie znał i których nie potrafił nazwać nawet w rodzimym języku. Dekoracyjny kieliszek do jajka przez długi czas uznawał za ozdobę religijną i to właśnie ten intrygujący przedmiot był jedną z pamiątek, które ku zdziwieniu Polaków zdecydował się przywieźć do Japonii. Drugim nietypowym suwenirem z Polski był plastikowy czerwony kwadracik służący do zaznaczania aktualnej daty na kalendarzu ściennym. Kazu niejednokrotnie przekonał się też, że nawet wykonanie prostych codziennych czynności może stanowić wyzwanie dla cudzoziemca. Był bezradny np. wobec polskiej pralki. Nie rozumiał, co oznaczają liczby wokół pokrętła maszyny, i nie wiedział, którą z wielu dostępnych opcji powinien wybrać, a to dlatego, że w jego kraju zawsze pierze się w zimnej wodzie, więc na japońskich pralkach nie ma żadnych oznaczeń dotyczących temperatury (Sasaki 2017, s. 85). Natomiast kaloryfer przez dłuższy czas stanowił dla niego tajemniczy przedmiot, którego przeznaczenia nie mógł się domyślić i który nazywał „białą metalową skrzynką” (Sasaki 2017, s. 79). Japończyk nie umiał też włączyć kuchenki, bo nigdy nie miał do czynienia z palnikami gazowymi, a konieczność ugotowania ryżu w garnku była niespodzianką dla przybysza z kraju, w którym każdy ma w domu specjalne urządzenie do tego celu. Tak więc w książce na pierwszy plan wysuwają się wyraźnie kulturowe odkrycia cudzoziemca $\mathrm{z}$ dziedziny polskiego realioznawstwa.

Jako smakosz Kazu był szczególnie zainteresowany polską kuchnią i otwarty na nowe odkrycia smakowe. Stał się amatorem jajecznicy, zapiekanek i pierogów ruskich. Ale już pierogi z truskawkami jako ciepłe danie główne na słodko okazały się wyzwaniem dla jego kulinarnej wyobraźni. Równie zaskakujące były dla Kazu wersje potraw z jego rodzimej kuchni serwowane w japońskich restauracjach w Polsce. Miał np. okazję przekonać się o istnieniu rodzajów sushi, o których nigdy wcześniej nie słyszał. Doceniał inwencję nadwiślańskich kucharzy, ale wyraźnie podkreślał, że w jego ojczyźnie takie ekstrawagancje nie spotkałyby się z aplauzem. ,„...] Dla świata japońskiego sushi ser, szczypiorek i awokado byliby [byłyby] najeźdźcami” (Sasaki 2017, s. 211). Dodawanie majonezu do sushi albo smażenie go w tempurze również zakrawało na herezję. Niektóre używane w Pol- 
sce produkty spożywcze były dla Japończyka na tyle egzotyczne, że nie wiedział, jak się je jada. Kasza przez długi czas wydawała mu się niejadalna, bo zamiast ją ugotować, próbował ją zjeść na surowo. Niespodzianką dla Japończyka okazał się też asortyment sklepu rybnego, w którym można kupić tylko śledzie i łososie. Swoje rozczarowanie szybko zrównoważył jednak refleksją natury interkulturowej - wyobraził sobie Polaków poszukujących w japońskim sklepie spożywczym konkretnego gatunku jabłek czy sera i musiał przyznał, że nie mieliby w czym wybierać (Sasaki 2017, s. 129).

Kazu niejednokrotnie doznał szoku kulturowego, czyli emocjonalnej reakcji na pobyt $\mathrm{w}$ innym otoczeniu kulturowym (Chutnik 2007, s. 49-50). Niekiedy stanowił on doświadczenie fizyczne, bo wiązał się z przekraczaniem przez Polaków granic, które w Japonii są nienaruszalne, a dotyczą przestrzeni osobistej i dotyku. Można sobie wyobrazić, że nieoczekiwane cmoknięcie w policzek przez nieznajomego mężczyznę w barze mogło stanowić dla chłopaka duży dyskomfort i stres. Jak większość Azjatów Japończycy zaliczani są bowiem do przedstawicieli kultur powściągliwych, a więc takich, w których ludzie zachowują znaczny dystans przestrzenny i w ogóle się nie dotykają w przestrzeni publicznej (Glondys, Bednarczyk 2020, s. 97-99). Kazu skomentował jednak całe zajście z humorem: „To był mój pierwszy pocałunek w Polsce, w barze... ale romantycznie! Szczęście w nieszczęściu nie pocałował mnie w usta” (Sasaki 2017, s. 51). Szokiem kulturowym okazała się też tak prozaiczna czynność jak wzięcie prysznica w polskim domu. Przede wszystkim Japończyk zastanawiał się, gdzie została ukryta kabina prysznicowa, bo nie przyszło mu do głowy, że tę funkcję może pełnić niczym nieosłonięta wanna, nad którą w dodatku suszyły się ubrania. Nie spodziewał się, że wielu Polaków jest zmuszonych do istnej ekwilibrystyki podczas codziennego mycia, tak by nie zalać wodą łazienki. Autor spuentował swoje doświadczenie polskim przysłowiem: „Kiedy wejdziesz między wrony, musisz krakać jak i one” (Sasaki 2017, s. 88), dając wyraz swojej gotowości do przystosowania się do polskich realiów i zwyczajów.

Podobnie jak Möller, Sasaki często przemieszczał się po Polsce pociągami. Dla niego również podróżowanie na pokładzie PKP było okazją do licznych zaskakujących odkryć w dziedzinie polskiej kultury. Okazało się, że nawet symbole obrazkowe sygnalizujące nakazy i zakazy - które z założenia mają przecież być uniwersalne - mogą wprawić cudzoziemca w konsternację. Kazu bardzo zdziwił ujęty w czerwone kółko rysunek przedstawiający puszkę i butelkę na tle okna pociągu. Gdyby chłopak odczytał ten symbol tak, jak należałoby go zinterpretować w Japonii, musiałby go zrozumieć nie jako zakaz, ale jako oficjalną zachętę do wyrzucania śmieci przez okno pociągu, bo „w Japonii czerwony okrąg $=$ można" (Sasaki 2017, s. 90). Japończyk nie potrafił również ukryć zdumienia, gdy współpasażerka, z którą nie zamienił ani słowa, pożegnała się z nim gromkim „do widzenia!", opuszczając przedział. 
Kazu miał też okazję się przekonać, że w Polsce funkcjonuje wiele stereotypów i skojarzeń związanych z Japonią. Wprawdzie na początku większość Polaków uznawała go za Chińczyka, ale gdy dowiadywali się, że oto stoi przed nimi przybysz z Kraju Kwitnącej Wiśni, w ich umysłach natychmiast uruchamiał się ciąg skojarzeń związanych z Japonią. Dominowały wśród nich wątki kulinarne oraz wybiórcza wiedza o dawnej i współczesnej kulturze japońskiej, zaczerpnięta zapewne z filmów Kurosawy i z reklam samochodów. Kiedy, poszukując pracy w zawodzie kucharza, Kazu przychodził na rozmowy kwalifikacyjne do japońskich restauracji w Polsce, od progu był brany przez obsługę za sushi mastera. Nazwisko Sasaki tak wielu Polakom kojarzyło się z nazwą popularnej japońskiej marki samochodowej, że Japończyk - zmęczony ciągłymi przeinaczeniami swojego patronimu - sam zaczął się w końcu przedstawiać jako Suzuki. Poznani w barach czy na imprezach Polacy chętnie nawiązywali z nim rozmowę. Kazu podał przykład takiego dialogu:

- Oh, you Japanese! TOYOTA! I love TOYOTA! I have TOYOTA! [...]

- So you samurai? Ha, ha. [...]

- Och, Japończyku! Lubię karate!! - Tu pokazał, co umie. - Aczooooooooh!!!

(Sasaki, 2017, s. 51)

Zaskoczeniem dla autora było również odkrycie peryfrastycznej i poetyckiej nazwy, którą Polacy zwykli określać jego ojczyznę: „Nie wiedziałem, że Polacy nazywają Japonię Krajem Kwitnącej Wiśni - przecież te drzewa kwitną tylko przez jeden tydzień w roku!" (Sasaki 2017, s. 132) Młody podróżnik uświadomił więc sobie, że dłuższy pobyt za granicą pozwala spojrzeć na własny kraj nie tylko z dystansu, ale też z perspektywy cudzoziemców, co bywa bardzo odkrywcze.

\section{6. ĆWICZENIA NA PODSTAWIE ANALIZOWANYCH TEKSTÓW}

Wybrane fragmenty przedstawionych tu książek mogą stanowić źródło licznych ćwiczeń mających na celu rozwijanie kompetencji międzykulturowej. Wiele doświadczeń i sytuacji opisanych przez Möllera i Sasakiego można zaprezentować na lekcji jako studia przypadku wymagające przeanalizowania pod kątem różnic czy nieporozumień kulturowych. Analiza ta może przybrać formę dyskusji na forum grupy czy pracy w mniejszych zespołach bądź tandemach, a także wypowiedzi pisemnej w ramach pracy indywidualnej. Aktywności studentów sprzyjać będą szczegółowe pytania, które z jednej strony zogniskują ich uwagę na ważnych aspektach danego epizodu w kontaktach interkulturowych, z drugiej zaś zachęcą ich do poszukiwania podobnych zdarzeń we własnej au- 
tobiografii spotkań międzykulturowych i do poddania ich pogłębionej refleksji. Takie ćwiczenia niewątpliwie skutkują zwiększaniem świadomości występowania różnic kulturowych między przedstawicielami różnych krajów i unaoczniają, że odmienność na tle kulturowym nie ogranicza się do innych świąt, tradycji i kulinariów, ale przejawia się też w sferach znacznie mniej namacalnych, a więc trudniej uchwytnych, a przy tym fundamentalnych dla każdej kultury - choćby takich jak wartości, normy zachowania czy relacje międzyludzkie. Zaproponowane pytania pomyślane są w taki sposób, by demaskować wszechobecny etnocentryzm oraz uzmysławiać studentom, że ich oczekiwania wobec innej kultury, a także jej oceny są podyktowane nieuświadomionym często, a jakże iluzorycznym przekonaniem, że to ich rodzima kultura wyznacza standardy tego, co „normalne”. Skłaniają bowiem do spojrzenia na własną kulturę z dystansu, do próby jej scharakteryzowania i do zastanowienia się nad tym, jak mogą ją postrzegać cudzoziemcy. Zaproponowane zadania udowadniają, że to, co wydaje się oczywiste i naturalne w Polsce, może dziwić , a nawet szokować ludzi z innych krajów. Ćwiczenia te uwrażliwiają również na wielość kulturowych perspektyw oraz zachęcają do zastąpienia odruchu wartościowania innych kultur uważną obserwacją i analitycznym namysłem nad tym, co nieznane i zaskakujące. Zwracają też uwagę na szkodliwe i zwykle nieprawdziwe uogólnienia w postaci stereotypów, które negatywnie rzutują na naszą percepcję danej kultury. $\mathrm{Na}$ konkretnych przykładach ukazują, że próba zrozumienia innej kultury jest kluczowa w komunikacji z jej reprezentantami. Kształtują więc postawę tolerancji, otwartości, ciekawości innych kultur oraz szacunku wobec nich. Przygotowują także do - jakże ważnej i niezbędnej we współczesnym świecie - roli mediatora interkulturowego, a więc osoby mogącej umożliwić bądź usprawnić komunikację ludzi, którzy nie mają kompetencji międzykulturowej koniecznej do udanego dialogu z rozmówcą z innego kraju. Reasumując, można stwierdzić, że zaproponowane aktywności ilustrują tezę mówiącą, że „podstawą kompetentnej (poprawnej i skutecznej) konwersacji międzykulturowej jest poczucie równości konwersujących stron oraz obustronne poszanowanie odmienności" (Zarzycka 2000, s. 71).

Wreszcie trzeba zauważyć, że wszystkie te ćwiczenia rozwijają jednocześnie sprawności językowe, a mianowicie czytanie ze zrozumieniem, mówienie i pisanie, a także poszerzają zasób słownictwa, zwłaszcza w takich zakresach semantycznych, jak: podróże, kulinaria, przedmioty codziennego użytku bądź przymiotniki służące do opisu wyglądu i emocji ludzi. Natomiast interpretowanie opisanych sytuacji, przyjmowanie różnych perspektyw w ocenie danego zdarzenia, wyjaśnianie reakcji i motywacji uczestników dialogu międzykulturowego, których to działań wymagają wszystkie przedstawione aktywności, to typowe przykłady mediacji. Działania mediacyjne, których roli w nauczaniu języka obcego poświęca się obecnie wiele uwagi (Kucharczyk 2020, s. 5-14), są w tych ćwiczeniach konieczne i występują w naturalnym, niewymuszonym kontekście. 
Oto kilka propozycji ćwiczeń odnoszących się bezpośrednio do omówionych fragmentów książek:

I. Przeczytaj poniższy fragment i odpowiedz na pytania.

Kazu, Japonia:

Kiedy słońce zaszło, wybrałem się do baru z moimi biznesmenami [...] Jak zwykle musiałem tłumaczyć się z tego, dlaczego jestem w Polsce. Dali mi wódkę, chociaż nic na ten temat nie mówiłem ani tym bardziej nie prosiłem. Uczyli mnie czegoś, krzyżowaliśmy ręce, a oni raz po raz zapewniali mnie radośnie:

- Yeah, we are frieeeends!

- Yeah!

(Sasaki 2017, s. 69)

1. Jaki rytuał rozpowszechniony w polskiej kulturze opisuje Kazu? Jak się nazywa, na czym polega i co oznacza?

2. Jak sądzisz, jak Japończyk czuł się w tej sytuacji? Dlaczego tak uważasz?

3. Jak ty czułabyś się / czułbyś się w takiej sytuacji? Dlaczego?

4. Czy w twojej kulturze jest podobny zwyczaj? Jak zwykle zachowują się ludzie w takiej sytuacji?

II. Pytania inspirowane fragmentami tekstów Möllera i Sasakiego - do dyskusji w parach, w większych zespołach lub na forum grupy.

1. Steffen pisze, że w Niemczech częstym tematem niezobowiązujących rozmów towarzyskich typu small talk jest piłka nożna, natomiast w Polsce - zbieranie grzybów. O czym zwykle rozmawiają ludzie w Twoim kraju, jeżeli chcą wybrać bezpieczny temat, na który większość osób będzie miała coś do powiedzenia? Czy sądzisz, że jest to temat, który sprawdziłby się w każdej kulturze?

2. Steffen często przygląda się pasażerom na dworcu i stara się rozpoznać wśród podróżnych swoich rodaków. Czy sądzisz, że, przyglądając się dużej grupie, domyśliłabyś/domyśliłbyś się od razu, kto pochodzi z twojego kraju? Co uważasz za cechy charakterystyczne dla swoich krajanów (np. ubiór, akcesoria, mowa ciała, wyraz twarzy)? Czy zdarzyło ci się pomylić podczas takiej zabawy w zgadywanie narodowości? Jeśli tak, jak myślisz, dlaczego?

3. Steffen zauważa, że Polacy i Niemcy inaczej posługują się sztućcami. Czy podczas pobytu za granicą dostrzegłaś/dostrzegłeś tego typu różnice dotyczące prozaicznych codziennych czynności? Na czym polegały? Jak się czułaś/czułeś, kiedy je odkryłaś/odkryłeś?

4. Kazu miał problem z obsługą pralki w Polsce, bo w Japonii te urządzenia wyglądają inaczej; nie wiedział też, co to jest kaloryfer, bo w jego kraju w domach są klimatyzatory. Czy zdarzyło ci się, że podczas pobytu za granicą nie wiedziałaś/wiedziałeś, do czego służy lub jak działa ja- 
kaś maszyna? Opowiedz o swoim doświadczeniu. Czy sądzisz, że jakieś sprzęty w twoim kraju mogą nastręczać trudności cudzoziemcom? Jakie i dlaczego?

5. Kazu opowiada, że w rozmowie z nim wielu Polaków wypowiadało słowa, które stereotypowo kojarzyły im się z Japonią, np. toyota, samuraj, sushi, karate, ninja. Czy masz podobne doświadczenia w kontaktach z cudzoziemcami? Jak się wtedy czułaś/czułeś? Czy wiesz, jaki jest za granicą stereotyp twojego kraju i jego mieszkańców? Czy uważasz, że odpowiada prawdzie?

6. Kazu nie wiedział, jak się je kaszę gryczaną, dziwiły go takie dania jak pierogi z truskawkami. Jak myślisz, jakie produkty i potrawy z twojego kraju mogą zaskoczyć cudzoziemców? Jakie dania innych kuchni okazały się dla ciebie szczególnie egzotyczne i dlaczego? Czy zdarzyło ci się, że danie typowe dla kuchni twojego kraju wyglądało i smakowało zupełnie inaczej za granicą?

7. Kazu przeżył szok kulturowy, kiedy nieznajoma osoba pocałowała go w policzek na powitanie. Czy zdarzyła ci się sytuacja w kontaktach z cudzoziemcami, kiedy poczułaś/poczułeś zakłopotanie, skrępowanie czy zażenowanie? Opowiedz o tym zdarzeniu. Czego dowiedziałaś/dowiedziałeś się dzięki niemu o innej i o swojej kulturze?

8. Kazu przywołuje znane polskie przysłowie „Kiedy wejdziesz między wrony, musisz krakać jak i one”. Jak rozumiesz to powiedzenie? Zgadzasz się z tym twierdzeniem? Czy kiedy podróżujesz do innego kraju, starasz się zachowywać tak jak jego mieszkańcy? Czy oczekujesz takiej postawy od cudzoziemców odwiedzających twój kraj?

III. Steffen i Kazu dokonują wielu ważnych obserwacji kulturowych podczas podróży pociągiem. Spróbuj krótko scharakteryzować własną kulturę przez pryzmat tego konkretnego kontekstu, jakim jest jazda koleją, z myślą o cudzoziemcach. Weź pod uwagę takie aspekty, jak: punktualność, symbole i oznaczenia, wystrój pociągu i organizacja przestrzeni na pokładzie, postawa konduktora i zachowanie pasażerów (np.: Czy inicjują rozmowę z innymi podróżnymi? Czy jedzą w przedziale? Czy w czasie podróży często opuszczają przypisane miejsce?) Zapisz te informacje w formie wskazówek albo instrukcji dla podróżnego z zagranicy.

\section{PODSUMOWANIE}

Publikacje Möllera i Sasakiego mogą stanowić kanwę licznych ćwiczeń rozwijających kompetencję międzykulturową na lekcji języka polskiego jako obcego. Na kartach ich książek toczy się bowiem nieustanny dialog międzykulturowy. 
Znajdziemy tam wiele przykładów nieporozumień i konfliktów na tle kulturowym, na których podstawie można skonstruować typy zadań popularne w treningach interkulturowych, tj. asymilatory kulturowe. Liczne fragmenty tych tekstów można też przekształcić na aktywności stymulujące obserwację różnic kulturowych oraz refleksję nad rodzimą kulturą i nad mechanizmami funkcjonowania stereotypów. Autentyczne wypowiedzi Niemca i Japończyka o doświadczeniach w Polsce i o ich percepcji polskiej kultury mają duży potencjał, by zachęcić uczących się do aktywnego udziału w zajęciach i skłonić ich do dzielenia się własnymi przeżyciami związanymi z poznawaniem Polski i zwyczajów jej mieszkańców. Niezręczna sytuacja towarzyska, trudności z załatwieniem jakiejś sprawy czy niewłaściwa interpretacja zachowania rozmówcy - takie i tym podobne epizody są przecież udziałem każdego Obcego, który wkracza do odmiennej kultury nieuchronnie sformatowany przez tę, w której się wychował, czy też przez nią zaprogramowany, jak określiłby to Geert Hofstede (Hofstede i in. 2011). Niewątpliwie takie sytuacje przydarzyły się również niejednemu cudzoziemcowi w Polsce, ale przecież przedstawiciela każdej kultury co innego dziwi, śmieszy czy szokuje w tradycjach i postawach Polaków. Nawet jeśli punktem wyjścia omawianych książek jest porównanie kultury polskiej z kulturą niemiecką lub japońską, w toku lekcji, zwłaszcza w grupie międzynarodowej, naturalnie dojdzie do poszerzenia perspektywy tej kulturowej konfrontacji - kultura polska zostanie zestawiona z kulturami reprezentowanymi przez uczestników zajęć. Stwarza to na lekcji nieocenioną możliwość odkrywania wielu różnych kultur, a taka ekspozycja na wielość wartości, norm zachowania i punktów widzenia nie tylko poszerza wiedzę o świecie i nie pozwala zasklepić się w ciasnych ramach własnej kultury, ale też sprzyja kształtowaniu krytycznej świadomości kulturowej i postawy tolerancji, a więc kluczowych komponentów kompetencji międzykulturowej (Byram 1997; Aleksandrowicz-Pędich 2005; Białek 2009; Boski 2010; Gębal 2019; Myczko 2005; Wilczyńska 2005). Książki Möllera i Sasakiego są zatem niezwykle inspirującym i pomocnym materiałem dla nauczycieli języka polskiego jako obcego poszukujących oryginalnych pomysłów na rozwijanie kompetencji międzykulturowej na zajęciach.

\section{BIBLIOGRAFIA}

Aleksandrowicz-Pędich L., 2005, Międzykulturowość na lekcjach języków obcych, Białystok.

Bandura E., 2007, Nauczyciel jako mediator międzykulturowy, Kraków.

Bauman Z., 2000, Ponowoczesność jako źródto cierpień, Warszawa.

Białek M., 2009, Ksztatcenie międzykulturowe w edukacji językowej, Wrocław.

Boski P., 2010, Kulturowe ramy zachowań społecznych. Podręcznik psychologii międzykulturowej, Warszawa.

Byram M., 1997, Teaching and Assessing Intercultural Communicative Competence, Clevedon. 
Byram M., 1997, Teaching and Assessing Intercultural Communicative Competence, Clevedon.

Byram M., Barrett M., Ipgrave J. i in., 2011, Autobiografia spotkań międzykulturowych, tłum. M. Kositorny, Warszawa, https://rm.coe.int/autobiografi-a-spotkanmiedzykulturowych/16806bf02f (dostęp: 01.08.2021).

Chutnik M., 2007, Szok kulturowy. Przyczyny, konsekwencje, przeciwdziałanie, Kraków.

Gębal P.E., 2019, Dydaktyka języków obcych. Wprowadzenie, Warszawa.

Glondys D. Bednarczyk M., 2020, Komunikacja międzykulturowa albo lepiej nie wychodź z domu, Kraków.

Hofstede G. i in., 2011, Kultury i organizacje. Zaprogramowanie umystu, tłum. M. Durska, Warszawa.

Karpińska-Musiał B., 2015, Międzykulturowość w glottodydaktyce, Gdańsk.

Kossakowska-Pisarek S., 2016, Wyzwania dla nauczyciela jako mediatora kulturowego w procesie kształcenia kompetencji interkulturowej, w: A. Jaroszewska i in. (red.), Wielojęzyczność i międzykulturowość na lekcji języka obcego - między teoria a praktyka nauczania, Warszawa, s. 53-63.

Kucharczyk R., 2020, Językowe działania mediacyjne na lekcjach języka obcego. Od teorii do praktyki dydaktycznej, „Języki Obce w Szkole” nr 2/2020, s. 5-14, http://jows.pl/artykuly/ jezykowe-dzialania-mediacyjne-na-lekcjach-jezyka-obcego (dostęp: 01.08.2021).

Meyer E., 2014, The Culture Map. Breaking Through The Invisible Boundaries of Global Business, New York.

Möller S., 2013, Berlin-Warszawa-Express. Pociag do Polski, Poznań.

Myczko K., 2005, Kompetencja interkulturowa jako cel ksztatcenia językowego, w: M. Mackiewicz (red.), Dydaktyka języków obcych a kompetencja kulturowa i komunikacja interkulturowa, Poznań, s. 27-35.

Pfeiffer W., 2001, Nauka języków obcych od praktyki do praktyki, Poznań.

Sasaki K., 2017, Jestem Kazu. Japończyk w Polsce, Bydgoszcz.

Simmel G., 1975, Obcy, w: id., Socjologia, tłum. M. Łukasiewicz, Warszawa, s. 504-512.

Spychała-Wawrzyniak M., 2016, Trening interkulturowy podczas lekcji języka obcego na przyktadzie języka hiszpańskiego, w: A. Jaroszewska i in. (red.), Wielojęzyczność i międzykulturowość na lekcji języka obcego - między teoria a praktyka nauczania, Warszawa, s. 77-93.

Torenc M., 2007, Nauczanie międzykulturowe - implikacje glottodydaktyczne, Wrocław.

Wilczyńska W., 2005, Czego potrzeba do udanej komunikacji interkulturowej?, w: M. Mackiewicz (red.), Dydaktyka języków obcych a kompetencja kulturowa i komunikacja interkulturowa, Poznań, s. 15-26.

Wilczyńska W., Mackiewicz M., Krajka J., 2019, Komunikacja interkulturowa. Wprowadzenie, Poznań.

Zarzycka G., 2000, Dialog międzykulturowy. Teoria oraz opis komunikowania się cudzoziemców przyswajajacych język polski, Łódź.

Żydek-Bednarczuk U., 2015, Spotkanie kultur. Komunikacja i edukacja międzykulturowa w glottodydaktyce, Katowice. 


\section{Justyna Zych \\ DEVELOPING INTERCULTURAL COMPETENCE THROUGH BOOKS ON POLAND WRITTEN BY FOREIGNERS}

Keywords: intercultural competence, intercultural communication, intercultural dialogue, Polish as a foreign language, books on Poland by foreigners

Abstract. In the present article, two books on Polish culture written by foreigners are analysed in detail from the point of view of the intercultural approach to teaching foreign languages, namely Berlin-Warszawa-Express. Pociag do Polski (2013) by Steffen Möller and Jestem Kazu. Japończyk $w$ Polsce (2017) by Kazutaki Sasaki. The author explains why this kind of text constitutes relevant material to develop intercultural competence during classes of Polish as a foreign language. The definition and methods of shaping intercultural competence are recalled in the article. The author emphasizes that books by foreigners create an opportunity to discover not only Polish culture, but also the cultures represented by the authors of the texts discussed. Moreover, they enable students to talk naturally about their own respective cultures in the context of comparisons with Polish culture. The article contains proposals of exercises aimed at promoting intercultural dialogue in the process of teaching Polish as a foreign language, which are based on chosen fragments of the analysed books. 